\title{
COMPARATIVE ANALYSIS OF MUSCLE SPLITTING VERSUS MUSCLE DIVIDING INCISION IN OPEN CHOLECYSTECTOMY
}

\author{
Sanjeev Singla ${ }^{1}$, Mamta Singla $^{2}$, Sundeep Singla ${ }^{3}$, Gaurav Thami ${ }^{4}$, Pushpinder Mallik ${ }^{5}$, Nivesh Aggarwal 6
}

\begin{abstract}
${ }^{1}$ Associate Professor, Department of Surgery, BPS Govt. Medical College, Khanpurkalan, Sonepat.
2 Professor, Department of Surgery, Muzaffarnagar Medical College.

${ }^{3}$ Assistant Professor, Department of Medicine, Rajshree Medical Research Institute, Bareilly.

${ }^{4}$ Assistant Professor, Department of Surgery, BPS Govt. Medical College, Khanpurkalan, Sonepat.

${ }_{5}^{5}$ Assistant Professor, Department of Surgery, BPS Govt. Medical College, Khanpurkalan, Sonepat.

${ }^{6}$ Professor, Department of Surgery, BPS Govt. Medical College, Khanpurkalan, Sonepat.
\end{abstract}

\begin{abstract}
Many incision have been advocated and used for open cholecystectomy. It is the muscle division which is supposed to be responsible for postoperative pain and the resultant local and systemic effects. This study was undertaken at BPSGMC for woman at Khanpurkalan to know whether muscle splitting technique for open cholecystectomy affects postoperative pain, discomfort and encourages early mobilization with reduction in hospital stay compared with traditional rectus muscle dividing open cholecystectomy. About one hundred female patients were randomly divided into two groups and observations were noted. Pain measurement was done by simple pain, sedation and nausea scoring system as given by Dr. Ann Coleman. The day on which patient became mobile and were fit for discharge were noted in both groups. It was found in this study that the muscle splitting incision is superior to muscle dividing incision in term of less pain, early mobility, less physiological alteration, decreased morbidity and hospital stay.
\end{abstract}

KEYWORDS: Cholecystectomy, Muscle, Dividing, Splitting, Incision.

HOW TO CITE THIS ARTICLE: Sanjeev Singla, Mamta Singla, Sundeep Singla, Gaurav Thami, Pushpinder Mallik, Nivesh Aggarwal. "Comparative Analysis of Muscle Splitting Versus Muscle Dividing Incision in Open Cholecystectomy." Journal of Evolution of Medical and Dental Sciences 2015; Vol. 4, Issue 93, November 19; Page: 15896-15898, DOI: 10.14260/jemds/2015/2310.

INTRODUCTION: With the introduction of laproscopic cholecystectomy in year 1987, surgical community witnessed a revolution in basic ideology. It has many advantages over conventional cholecystectomy, but has its own disadvantages in the form of $\mathrm{CO}_{2}$ toxicity, expensive instruments, increased incidence of bile duct injury and about $10 \%$ of patients require open cholecystectomy whether owing to contraindication to laparoscopic approach or because of conversion to open technique become necessary following laparoscopy.1,2,3

Many incision have been advocated and used for open cholecystectomy. It is the muscle division which is supposed to be responsible for postoperative pain and the resultant local and systemic effects.

This study was undertaken to know whether muscle splitting technique for open cholecystectomy affects postoperative pain, discomfort and encourages early mobilization with reduction in hospital stay compared with traditional rectus muscle dividing open cholecystectomy.

Method: This study has been conducted at BPSGMC (W), Sonepat Dec. 2013, Dec. 2014 in 100 female patients age group between $20 y$ rs to $50 y r s$, after taking their due written consent.

Financial or Other, Competing Interest: None.

Submission 31-10-2015, Peer Review 02-11-2015,

Acceptance 13-11-2015, Published 19-11-2015.

Corresponding Author:

Dr. Sanjeev Singla,

Associate Professor

Department of Surgery,

BPS Govt. Medical College,

Khanpurkalan, Sonepat.

E-mail: sanjeev44@live.in

DOI:10.14260/jemds/2015/2310
All male patients with history or presently having cholecystitis, jaundice, complicated cholelithiasis, or patients suffering from chronic diseases were excluded from study.

All patients were investigated for confirmation of diagnosis and anaesthetic fitness. Patients were randomized in two groups viz., muscle splitting and muscle dividing group and except for the manner in which anterior abdominal wall was dealt with, the cholecystectomy was otherwise standard and same for both the group. Incision length was kept less than $10 \mathrm{cmt}$.

A transverse subcostal incision was used in all cases. Anterior rectus sheath was divided in the line of the incision. Rectus muscle was cut along the line of incision in muscle cutting group, but in muscle splitting group rectus muscle was split bluntly in the line of its fibres approximately 2.5 cmts to the right of linea alba. Rectus muscle was then retracted medially and laterally to expose the posterior rectus sheath which was then divided vertically and peritoneal cavity entered in both the group.

OBSERVATION: In postoperative period, all patients were interviewed and observation was noted.

\begin{tabular}{|c|c|c|}
\hline Age (in yrs) & Group I & Group II \\
\hline $20-30$ & 13 & 11 \\
\hline $30-40$ & 23 & 24 \\
\hline $40-50$ & 14 & 15 \\
\hline Mean age & 40.42 & 42.84 \\
\hline $\begin{array}{c}\text { Standard } \\
\text { Deviation }\end{array}$ & 13.04 & 12.68 \\
\hline $\begin{array}{c}\text { Pvalue }>.05 \\
\text { t value.7072 }\end{array}$ & \\
\hline \multicolumn{2}{|c|}{ Table 1: Distribution of age } \\
\hline
\end{tabular}




\begin{tabular}{|c|c|c|}
\hline & Group I & Group II \\
\hline Mean & 6.322 & 6.372 \\
\hline SD & .559 & .498 \\
\hline \multicolumn{2}{|c|}{ Table 2: Mean length of incision (in cmts) } \\
of patients of both group
\end{tabular}

\begin{tabular}{|c|c|c|c|}
\hline Day & Pain Score & Group I & Group II \\
\hline \multirow{4}{*}{1} & 0 & 0 & 0 \\
\hline & 1 & 22 & 3 \\
\hline & 2 & 28 & 23 \\
\hline & 3 & 0 & 24 \\
\hline Mean & & 1.560 & 2.420 \\
\hline \multicolumn{4}{|c|}{$\mathrm{P}$ value $<0.001 \mathrm{t}$ value 7.711} \\
\hline \multirow{4}{*}{2} & 0 & 8 & 0 \\
\hline & 1 & 39 & 23 \\
\hline & 2 & 3 & 25 \\
\hline & 3 & 0 & 2 \\
\hline Mean & & .900 & 1.580 \\
\hline \multicolumn{4}{|c|}{$\mathrm{p}$ value $<0.001 \mathrm{t}$ value 6.513} \\
\hline \multirow{4}{*}{3} & 0 & 23 & 2 \\
\hline & 1 & 27 & 42 \\
\hline & 2 & 0 & 6 \\
\hline & 3 & 0 & 0 \\
\hline Mean & & .600 & 1.102 \\
\hline \multicolumn{4}{|c|}{$\mathrm{p}$ value $<0.001 \mathrm{t}$ value 7.201} \\
\hline \multirow{4}{*}{4} & 0 & 44 & 14 \\
\hline & 1 & 6 & 36 \\
\hline & 2 & 0 & 0 \\
\hline & 3 & 0 & 0 \\
\hline Mean & & .150 & .735 \\
\hline \multicolumn{4}{|c|}{$\mathrm{p}$ value $<0.001 \mathrm{t}$ value 7.201} \\
\hline \multicolumn{4}{|c|}{$\begin{array}{l}\text { Table 3: Value of pain score } \\
\text { in patients of both groups }\end{array}$} \\
\hline
\end{tabular}

Group 1 Group 2:

\begin{tabular}{|c|c|c|c|c|}
\hline & $\begin{array}{c}\text { Mean } \\
\text { Standard } \\
\text { Deviation }\end{array}$ & $\begin{array}{c}\text { Mean } \\
\text { Standard } \\
\text { Deviation }\end{array}$ & $\begin{array}{c}\mathbf{P} \\
\text { value }\end{array}$ & $\begin{array}{c}\text { T } \\
\text { value }\end{array}$ \\
\hline Day1 & 1.620 .725 & 2.380 .635 & $<0.001$ & 5.516 \\
\hline Day2 & 1.160 .738 & 1.720 .701 & $<0.001$ & 3.890 \\
\hline Day3 & .800 .694 & 1.143 .645 & $<0.05$ & 2.560 \\
\hline Day4 & .359 .486 & .367 .528 & $>0.05$ & 0.079 \\
\hline
\end{tabular}

Table 4: Means of analgesic doses taken by patients of both groups for 4 consecutive postoperative days

Group 1 Group 2:

\begin{tabular}{|c|c|c|c|}
\hline & $\begin{array}{c}\text { Mean } \\
\text { Distance } \\
\text { S. D. } \\
\text { walked }\end{array}$ & $\begin{array}{c}\text { Mean } \\
\text { Distance } \\
\text { S.D. } \\
\text { walked }\end{array}$ & $\begin{array}{c}\text { P } \\
\text { value }\end{array}$ \\
\hline Day1 & 22.8018 .484 & $9.8 \mathrm{~m} 1.414$ & $<0.001$ \\
\hline Day2 & 500 & 48.47 .918 & $>0.05$ \\
\hline Day3 & 500 & 500 & $>0.05$ \\
\hline Day4 & 500 & 500 & $>0.05$ \\
\hline \multicolumn{4}{|c|}{$\begin{array}{c}\text { Table 5: Distance walked by } \\
\text { the patients of both groups }\end{array}$} \\
\hline
\end{tabular}

\begin{tabular}{|c|c|c|}
\hline & Mean & S. D. \\
\hline Group 1 & 2.040 & .283 \\
\hline Group 2 & 2.480 & .505 \\
\hline \multicolumn{2}{|c|}{ Table 6: Number of days on which patient } \\
was able to climb stairs comfortably
\end{tabular}

\begin{tabular}{|c|c|c|}
\hline Day & $\begin{array}{c}\text { Group 1 } \\
\text { Number } \\
\text { of patients }\end{array}$ & $\begin{array}{c}\text { Group 2 } \\
\text { Number } \\
\text { of patients }\end{array}$ \\
\hline 1 & 0 & 0 \\
\hline 2 & 43 & 8 \\
\hline 3 & 6 & 24 \\
\hline 4 & 1 & 18 \\
\hline Mean S.D. & 2.160 & 3.2 \\
\hline P value<.001 & .422 & .536 \\
\hline \multicolumn{3}{|c|}{ Table 7: The day patient } \\
considered fit for discharge \\
\hline \multicolumn{2}{|c}{} \\
\hline
\end{tabular}

DISCUSSION: This study was done at BPSGMC Khanpurkalan, Sonepat. In this study, we compared the results of both group 1 and 2 patients. Pain measurement was done by simple pain, sedation and nausea scoring system as given by Dr. Ann Coleman. ${ }^{4}$

\section{Measurement of Pain:}

a) Pain Score: Patients of group 1 suffered from less pain as compared to group 2 patients, as mean pain score of 4 consecutive days was less for patients of group 1 with $P$ value $<0.001$ (Table 4). Decrease in pain in group 1 patients is mainly attributed to splitting of rectus muscle rather division of muscle. As when muscle is cut, it goes into muscle spasm which leads to pain. Merrill attributed less pain to intact vascularisation and innervation of the muscle with splitting incision. ${ }^{5}$

b) Analgesic doses taken by the patient: Group 1 patients because of less pain took less number of analgesic doses as compared to group group 2 patients (Table 5). Goco et al.,6 Reddick et al.,7 and 0 'Dwyer et al.,8 in their separate studies had reported mean postoperative analgesic doses in each patient as 1, 2 and 4. Baguley. ${ }^{9}$ reported that muscle splitting technique appears to be superior in terms of postoperative pain and discomfort to the muscle dividing method.

2. Mobility: Group 1 patients because of less pain were more mobile as compared to group 2 patients. (P value $<.001$ for D1). All the patients of group 1 were fully mobile by day 2 , while all the patients of group 2 were fully mobile by day 3 . Dr P. E. Baguley in his study reported that $100 \%$ patients of muscle splitting group were fully mobile by day 3 as compared to $75 \%$ patients of muscle dividing group.

3. Day on which patient was fit for discharge: Patients were considered fit for discharge when they had no respiratory problem, moved bowel, no need of regular intake of analgesics, took food and drugs orally and were ambulatory. In our study, $86 \%$ patients of group 1 were fit for discharge within 48 hours of surgery, whereas only $64 \%$ of patients of group 2 were fit for discharge on third postoperative day. Thus group1 patients were fit for discharge earlier as compared to group 2 patients. This was mainly because of less pain and early mobility

In this era of concern for the expense of health care delivery, strategies that reduce length of hospitalisation and decrease duration of disability stimulate tremendous interest among the medical and lay communities. The muscle splitting incision is superior to muscle dividing incision in term of less pain, early mobility, less physiological alteration, decreased 
morbidity and hospital stay. Splitting can be extended in vertical fashion without increasing horizontal length of incision. The incision is grid-iron type and for anatomical reasons resultant strength is better. This procedure allow the surgeon to treat patients with cholecystectomies in the fashion to which the surgeon is accustomed and still markedly reduces the hospital stay. This procedure does not require any special training or equipment. The patients are most willing to accept this type of procedure after it has been shown to be successful and accompanied by decreased morbidity and moderate financial benefits. Thus muscle splitting cholecystectomy is a viable option in poor and developing countries like India.

\section{BIBLIOGRAPHY:}

1. Schirmer BD, Winters KL, Edlich RF. Cholelithiasis and cholecystitis. J Long Term Eff Med Implants 2005; 15 (3):329-38.

2. Sicklick JK, Camp MS, Lillemoe KD, Melton GB, Yeo CJ, Campbell KA, et al. Surgical management of bile duct injuries sustained during laparoscopic cholecystectomy: Perioperative results in 200 patients. Ann Surg 2005 May; 241(5):786-92; discussion 793-5.
3. McCloy R, Randall D, Schug SA, Kehlet H, Simanski C, Bonnet $\mathrm{F}$, et al. Is smaller necessarily better? A systematic review comparing the effects of minilaparoscopic and conventional laparoscopic cholecystectomy on patient outcomes. Surg Endosc 2008 Dec; 22(12):2541-53.

4. Coleman A. Postoperative pain control. Surgery1995; 6: 201-4.

5. Merril JR. Minimal trauma cholecystectomy (A no touch procedure as well). Am Surg 1988; 54: 256-61.

6. Goco IR, Chambers LG. "Mini-cholecystectomy" and operative cholangiograms, a means of cost containment. Am Surg1983; 49: 143-45.

7. Reddick EJ, Olsen D. Laproscopic laser cholecystectomy. A comparison with minicholecystectomy. Surg Endosc 1989; 3: 131-33.

8. O'Dwyer PJ, Murphy JJ, O'Higgins NJ. Cholecystectomy through a $5 \mathrm{~cm}$ subcostal incision.Br J Surg1990; 77: 1189-90.

9. Baguley P, Gara C, Gagic N. Open cholecystectomy: Muscle splitting versus muscle dividing incision: A randomised study. J R Col Surg Edin1995;40:230-32. 